\title{
FAKTOR-FAKTOR YANG MEMPENGARUHI MINAT SISWA MADRASAH ALIYAH NEGERI (MAN) 2 JEMBRANA KELAS XII UNTUK MELANJUTKAN STUDI KE PERGURUAN TINGGI PADA TAHUN AJARAN 2017/2018
}

\author{
Nur Munira \\ Jurusan Pendidikan Ekonomi \\ Universitas Pendidikan Ganesha \\ Singaraja, Indonesia \\ e-mail: nurmuniramawardi@gmail.com
}

\begin{abstract}
Abstrak
Penelitian ini bertujuan untuk mengetahui faktor-faktor yang mempengaruhi minat siswa untuk melanjutkan studi, dan faktor-faktor yang paling dominan mempengaruhi minat siswa Madrasah Aliyah Negeri (MAN) 2 Jembrana kelas XII untuk melanjutkan studi ke perguruan tinggi. Jenis penelitian ini adalah penelitian faktorial. Data dikumpulkan dengan menggunakan metode kuesioner dan dianalisis dengan menggunakan analisis faktor dengan bantuan program SPSS for windows 21.0. Hasil penelitian menunjukkan bahwa terdapat 9 (sembilan) faktor yang mempengaruhi minat siswa Madrasah Aliyah Negeri (MAN) 2 Jembrana kelas XII untuk melanjutkan studi ke perguruan tinggi yaitu faktor bakat, faktor kepribadian, faktor motivasi, faktor prestasi, faktor sikap, faktor keluarga, faktor sekolah, faktor lingkungan, dan faktor teman-teman. Faktor yang paling dominan mempengaruhi minat siswa Madrasah Aliyah Negeri (MAN) 2 Jembrana kelas XII untuk melanjutkan studi ke perguruan tinggi adalah faktor bakat dengan nilai varimax rotation sebesar $42,163 \%$, dan faktor kepribadian dengan nilai varimax rotation sebesar $19,877 \%$.
\end{abstract}

Kata Kunci: minat, melanjutkan studi.

\begin{abstract}
This study aims at find factors influencing the interest students for continuing their studies, and factors most dominant influencing the interest students Madrasah Aliyah Negeri (MAN) 2 Jembrana for continuing studies to collage. The type of this study was factorial research. Data were collected using by method the questionnaire and were analyzed using a factor analysis with spss 21.0 for windows. The result of the study showed there were 9 (nine) of factors affect interest students Madrasah Aliyah Negeri (MAN) 2 Jembrana class XII for continuing their studies to college is a factor talent, personality factor, factor motivation, factor achievement, factor attitude, factor family, the school, factor environmental public, factors friends. Factors most dominant that affects interest students Madrasah Aliyah Negeri (MAN) 2 Jembrana class XII for continuing their studies to college is a factor talent much as varimax rotation $42,163 \%$, and the factor personality varimax rotation much as $19,877 \%$.
\end{abstract}

Keywords: interest, continuing their studies.

\section{PENDAHULUAN}

Pendidikan memiliki peran penting

dalam membawa perubahan yang positif

dalam pembangunan suatu bangsa.

Pendidikan merupakan salah satu instrumen utama dalam mengembangkan kemampuan atau potensi yang dimiliki generasi penerus suatu bangsa agar menjadi sumber daya manusia yang berkualitas. Untuk mencapai tujuan tersebut serangkaian usaha yang telah dilakukan oleh pemerintah, salah satunya 
adalah pengembangan lembaga-lembaga pendidikan tinggi yakni lembaga perguruan tinggi baik negeri maupun swasta.

Pendidikan tinggi memberikan kontribusi dalam menyiapkan sumber daya manusia yang handal dan mampu bersaing. "Pendidikan tinggi mencakup program pendidikan diploma, sarjana, magister, spesialis, dan doktor yang diselenggarakan oleh perguruan tinggi" (Rohman, 2009:225). Dengan demikian apabila melanjutkan studi ke perguruan tinggi maka diharapkan akan memiliki bekal pengetahuan dan kecakapan sesuai dengan program studi yang ditempuh yang nantinya menjadi modal dasar untuk dapat lebih berkompeten di dunia kerja. Apalagi mengingat persaingan di dunia usaha kini semakin ketat, banyak lapangan pekerjaan yang membutuhkan tenaga kerja dengan gelar diploma maupun sarjana. Oleh karena itu menempuh pendidikan menengah saja tidak cukup untuk dapat bersaing dalam dunia kerja untuk memperoleh kesempatan kerja. Crow mengemukakan bahwa, "minat berhubungan dengan gaya gerak yang mendorong seseorang untuk menghadapi atau berurusan dengan orang, benda, kegiatan, pengalaman yang dirangsang oleh kegiatan itu sendiri, hal ini berarti siswa yang memiliki minat akan mempunyai dorongan dan kemauan yang tinggi untuk melanjutkan ke perguruan tinggi, sehingga cenderung melakukan usaha-usaha agar keinginannya tercapai" (dalam Djaali, 2012:121)

Minat dapat didefinisikan secara sederhana yaitu kecendrungan individu (siswa) untuk memusatkan perhatian terhadap objek atau situasi tertentu. Dalam hal ini minat siswa untuk melanjutkan studi ke perguruan tinggi dapat dilihat dari usaha untuk menggali informasi tentang perguruan tinggi yang diinginkannya. Minat tersebut tidak tumbuh dengan sendirinya melainkan terdapat faktor-faktor yang dapat membangkitkan minat tersebut. Seperti halnya yang diungkapkan oleh Bernard bahwa, "minat tidak timbul secara tiba-tiba/spontan, melainkan timbul dari partisipasi, pengalaman, kebiasaan pada waktu belajar dan bekerja, minat tersebut dapat dipengaruhi oleh banyak faktor baik faktor dari luar maupun dari dalam siswa (dalam Sardiman, 2011:76). Menurut Slameto (2010:54), "faktor dari dalam meliputi faktor biologis, faktor psikologis, faktor kelelahan. Faktor dari luar meliputi faktor keluarga, faktor sekolah, faktor masyarakat.

Berdasarkan data yang diperoleh dari Waka Kurikulum Madrasah Aliyah Negeri (MAN) 2 Jembrana, menunjukkan bahwa minat siswa lulusan Madrasah Aliyah Negeri (MAN) 2 Jembrana yang melanjutkan studi ke perguruan tinggi masih tergolong rendah. Pada tahun 2012 dengan presentase sebesar $32 \%$, jumlah alumni sebanyak 34 siswa dan yang melanjutkan 11 siswa. Tahun 2013 dengan presentase sebesar 17\%, jumlah alumni sebanyak 51 siswa dan yang melanjutkan 9 siswa. Tahun 2014 dengan presentase sebesar $13 \%$, jumlah alumni sebanyak 89 siswa dan yang melanjutkan 12 siswa. Tahun 2015 dengan presentase sebesar $25 \%$, jumlah alumni sebanyak 44 siswa dan yang melanjutkan 11 siswa. Tahun 2016 dengan presentase sebesar 33\%, jumlah alumni sebanyak 51 siswa dan yang melanjutkan 17 siswa.

Hasil survei di Madrasah Aliyah Negeri (MAN) 2 Jembrana tidak semua lulusan dapat melanjutkan studi ke perguruan tinggi, beberapa ada yang menjadi pengangguran, dan beberapa lagi memilih bekerja untuk membantu perekonomian keluarganya. Selain itu faktor status sosial ekonomi orang tua berperan penting dalam kelanjutan studi siswa. Status sosial ekonomi adalah gambaran tentang keadaan seseorang atau suatu masyarakat yang ditinjau dari segi sosial ekonomi, gambaran itu seperti tingkat pendidikan, pendapatan dan sebagainya. Kondisi sosial ekonomi orang tua dapat mempengaruhi sikap serta tingkat aspirasi orang tua terhadap pendidikan anak. Abdullah Idi (2010:180) mengemukakan bahwa, "anak memiliki kesempatan lebih luas untuk mengembangkan pengetahuan dan beragam kecakapan atas jaminan dan dukungan ekonomi orang tua". Dengan demikian orang tua yang dianggap memiliki status sosial ekonomi yang tinggi di masyarakat akan memiliki perhatian 
yang tinggi untuk pendidikan anaknya. Namun apabila status sosial ekonomi orang tua rendah, maka dapat menghambat siswa untuk melanjutkan studi ke Perguruan Tinggi. Hal ini dikarenakan biaya untuk melanjutkan ke Perguruan Tinggi tidak sedikit dan bagi keluarga yang status sosial ekonominya rendah akan merasa keberatan. Apalagi ditambah naiknya biaya pendidikan di Perguruan Tinggi yang mana dari tahun ke tahun seringkali membuat orang tua tidak mampu untuk menyediakan dana studi tersebut.

Menurut Notoatmodjo (2003) pendidikan merupakan segala upaya yang direncanakan untuk mempengaruhi orang lain baik individu, kelompok, atau masyarakat sehingga mereka melakukan apa yang diharapkan oleh pelaku pendidikan. Menurut Langeveld pendidikan ialah "setiap usaha, pengaruh, perlindungan dan bantuan yang diberikan kepada anak yang tertuju kepada anak itu, atau lebih tepat membantu agar anak cukup cakap melaksanakan tugas hidupnya sendiri. Pengaruh itu datangnya dari orang dewasa seperti buku, putaran hidup sehari-hari, dan sebagainya dan ditujukan kepada orang yang belum dewasa" (dalam Hasbullah, 2008:2). Menurut Siswoyo dkk (2007) pendidikan adalah "proses dimana masyarakat, melalui lembaga-lembaga pendidikan (sekolah, perguruan tinggi atau melalui lembaga-lembaga lain), dengan sengaja mentransformasikan warisan budayanya, yaitu pengatahuan, nilai-nilai dan keterampilan-keterampilan, dan generasi ke generasi". Menurut UU RI No.20 Tahun 2003, pendidikan adalah usaha sadar dan terencana untuk mewujudkan suasana belajar dan proses pembelajaran agar peserta didik secara aktif mengembangkan potensi dirinya untuk memiliki kekuatan spiritual keagamaan, pengendalian diri, kepribadian, kecerdasan, akhlak mulia, serta keterampilan yang diperlukan dirinya, masyarakat, bangsa dan negara. Dalam UU No. 20 tahun 2003 Pasal 13 ayat 1 dinyatakan bahwa jalur pendidikan terdiri dari pendidikan formal, non-formal dan informal. (1) Pendidikan formal adalah jalur pendidikan yang terstruktur dan berjenjang yang terdiri atas pendidikan anak usia dini (TK/RA), pendidikan dasar (SD/MI), pendidikan menengah (SMP/MTS dan SMA/MA/SMK), dan pendidikan tinggi (Universitas); (2) Pendidikan nonformal adalah jalur pendidikan di luar pendidikan formal yang dapat dilaksanakan secara terstruktur dan berjenjang. Pendidikan nonformal paling banyak terdapat pada usia dini, serta pendidikan dasar, adalah TPA atau Taman Pendidikan Al Quran,yang banyak terdapat di Masjid dan Sekolah Minggu, yang terdapat di semua Gereja. Selain itu, ada juga berbagai kursus, diantaranya kursus musik, bimbingan belajar dan sebagainya; (3) Pendidikan informal adalah jalur pendidikan keluarga dan lingkungan berbentuk kegiatan belajar secara mandiri yang dilakukan secara sadar dan bertanggung jawab. Hasil pendidikan informal diakui sama dengan pendidikan formal dan nonformal setelah peserta didik lulus ujian sesuai dengan standar nasional pendidikan. Tujuan dari pendidikan menurut Undang-Undang Nomor 20 tahun 2003 tentang Sistem Pendidikan Nasional, Pasal 3 adalah mengembangkan potensi peserta didik agar menjadi manusia yang beriman dan bertakwa kepada Tuhan Yang Maha Esa, berakhlak mulia, sehat, berilmu, cakap, kreatif, mandiri, dan menjadi warga negara yang demokratis serta bertanggung jawab.

Berdasarkan pengertian di atas maka dapat disimpulkan bahwa pendidikan adalah suatu usaha sadar terencana untuk mewujudkan proses belajar mengembangkan potensi diri, menambah pengalaman kemampuan agar menjadi manusia yang berakal, berkerakter, bermoral, bermartabat serta menjadi manusia seutuhnya. Untuk mencapai tujuan pendidikaan nasional yang antara lain yaitu meningkatkan ketaqwaan kepada Tuhan Yang Maha Esa, kecerdasan dan keterampilan maka salah satu usaha yang ditingkatkan adalah menumbuhkan kemandirian belajar pada setiap warga negara terutaama pada siswa diberbagai sekolah, dengan menumbuhkan minat dan motivasi belajar yang baik.

Crow mengemukakan bahwa, "minat berhubungan dengan gaya gerak 
yang mendorong seseorang untuk menghadapi atau berurusan dengan orang, benda, kegiatan, pengalaman yang dirangsang oleh kegiatan itu sendiri, hal ini berarti siswa yang memiliki minat akan mempunyai dorongan dan kemauan yang tinggi untuk melanjutkan ke perguruan tinggi, sehingga cenderung melakukan usaha-usaha agar keinginannya tercapai (dalam Djaali, 2012:121). Menurut Slameto (2010) bahwa minat diartikan sebagai suatu rasa lebih suka dan rasa ketertarikan pada suatu hal atau aktivitas, tanpa ada yang menyuruh. Minat pada dasarnya adalah penerimaan akan suatu hubungan antara diri sendiri dengan sesuatu di luar diri. Menurut Syah (2004:136) minat adalah kecenderungan dan kegairahan yang tinggi atau keinginan yang besar terhadap sesuatu. Sedangkan Djaali (2008) berpendapat bahwa minat dapat diekspresikan melalui pernyataan yang menunjukkan bahwa siswa lebih menyukai suatu hal dari pada hal lainnya, dapat pula dimanifestasikan melalui partisipasi dalam suatu aktivitas.

Menurut Daryanto (2009) minat adalah kecenderungan yang tetap untuk memperhatikan dan mengenang beberapa kegiatan. Kegiatan yang diminati seseorang diperhatikan terus menerus yang disertai dengan rasa senang. Seseorang yang mempunyai minat pada suatu obyek, dia akan tertarik dengan obyek tersebut. Biasanya orang tersebut akan selalu mengikuti perkembangan informasi tentang obyek tersebut. Minat pada suatu obyek akan mendorong seseorang untuk mencari tahu dan mempelajari obyek tersebut dan dia akan mengikuti aktivitas yang berhubungan dengan obyek tersebut. Menurut Sobur (2011:246) minat merupakan keinginan yang erat pula hubungannya dengan perhatian yang dimiliki, karena perhatian mengarahkan timbulnya kehendak pada seseorang. Juga erat hubungannya dengan kondisi psikis seperti senang, bergairah, dan seterusnya". Menurut Djamarah (2011), minat dapat diekspresikan melalui pernyataan lebih menyukai sesuatu daripada yang lainnya, partisipasi aktif dalam suatu kegiatan, memberikan perhatian yang lebih besar terhadap sesuatu yang diminatinya tanpa menghiraukan yang lain. Seperti halnya yang diungkapkan oleh Bernard bahwa, "minat tidak timbul secara tibatiba/spontan, melainkan timbul dari partisipasi, pengalaman, kebiasaan pada waktu belajar dan bekerja" (dalam Sardiman, 2011:76). Minat tersebut dapat dipengaruhi oleh banyak faktor baik faktor dari luar maupun dari dalam diri siswa.

Menurut Slameto (2010), "faktor dari dalam siswa meliputi faktor biologis (seperti kesehatan dan cacat tubuh), faktor psikologis (seperti intelegensi, perhatian, minat, bakat, motif, kematangan, dan kesiapan), faktor kelelahan baik secara jasmani maaupun rohani. Faktor dari luar siswa meliputi faktor keluarga (cara orang tua mendidik, relasi antar anggota keluarga,suasana rumah, keadaan ekonomi keluarga, pengeriaan orang tua, dan latar belakang kebudayaan), faktor sekolah (metode mengajar, kurikulum, relasi guru dengan siswa, relasii siswa dengan siswa, disiplin sekolah, alat pelajaran, waktu sekolah, standar pelajaran, keadaan gedung, metode belajar, dan tugas rumah), faktor masyarakat (keagaitan siswa dalam masyaaakat, media masa, tean bergaul, dan bentuk kehidupan masyarakat)". Berdasarkan beberapa pendapat di atas dapat disimpulkan bahwa minat adalah kecenderungan dari dalam individu untuk tertarik pada sesuatu obyek atau menyenangi sesuatu obyek, semakin kuat atau dekat hubungan tersebut maka semakin besar minatnya. Jadi dapat dikatakan bahwa minat dipengauhi oleh faktor internal dan faktor eksaternal.

Menurut Crow dan Crow bahwa faktor-faktor yang mempengaruhi atau mendasari timbulnya minat adalah sebagai berikut. (a) Minat dari dalam, yaitu yang berasal dari dalam individu yang mendorong pemusatan perhatian dan keterlibatan mental secara aktif; (b) faktor motif sosial, yaitu merupakan faktor yang membankitkan minat pada hal-hal tertentu yang ada hubunganna dengan pemenuhaan hubungan sosisal bagi dirinya, misalnya pendidikan yang lebih tinggi; (c) faktor emosional, merupakan faktor perasaan yang erat kaitannya 
dengan minat seseorang terhadap suatu obyek (dalam Abror, 1984). Aktivitas yang memberikaan keberhasilan dan kesuksesan akan menimbulkan perasaan senang dan puas sehingga berpengaruh pada bidang yang bersangkutan. Dari beberapa pendapat tersebut, maka dapat disimpulkan faktor-faktor yang mempengaruhi minat siswa melanjutkan studi ke perguruan tinggi dapat digolongkan menjadi dua yaitu faktor internal dan faktor eksternal.

Faktor Internal yang meliputi (a) Potensi diri (bakat), menurut Slameto (2010:57) bakat adalah kemampuan untuk belajar. Kemampuan itu baru akan terealisasi menjadi kecakapan yang nyata sesudah belajar atau berlatih. Bakat akan mempengaruhi tinggi rendahnya prestasi belajar bidang-bidang studi tertentu. Bakat mempengaruhi dalam pemilihan bidang saat melanjutkan studi ke perguruan tinggi; (b) cita-cita, menurut Sardiman (2011:89) cita-cita adalah sesuatu yang ingin kita capai disertai perencanaan dan tindakan kita untuk mencapainya. Cita-cita menjadi motivasi seseorang untuk mencapai tujuan hidupnya; (c) kepribadian, kajian tentang kepribadian seseorang dijelaskan oleh Yusuf \& Nurihsan (2008:1) kepribadian atau personality merupakan salah satu kajian psikologi yang lahir berdasarkan pemikiran, kajian atau temuan-temuan (hasil praktik penanganan kasus) para ahli; (d) motivasi, suatu proses yang menentukan tingkat kegiatan, intensitas, konsistensi, serta arah umum dari tingkh laku manusia, merupakan konsep yang rumit dan berkaitan dengan konsepkonsep lain seperti minat, konsep diri, sikap, dan sebagainya; (e) prestasi, prestasi belajar digunakan untuk menunjukkan hasil yang optimal dari suatu aktivitas belajar. Djamarah (2011:19) berpendapat bahwa prestasi belajar adalah hasil dari suatu kegiatan yang telah dikerjakan, diciptakan, baik secara individual atau kelompok; (f) Sikap, Syah (2004:135) mengemukakan bahwa sikap adalah gejala internal yang berdimensi afektif berupa kecendrungan untuk mereaksi atau merespon dengan cara yang relatif tetap terhadap objek berupa orang, barang, dan sebagainya, baik secara positif maupun negatif.

Faktor Eksternal meliputi, (a) keluarga, menurut Yusuf \& Sugandhi (2011) lingkungan keluarga dipandang sebagai faktor penentu yang utama terhadap perkembangan anak. Keluarga merupakan lingkungan yang pertama mengenalkan nilai-nilai kehidupan kepada anak dan keluarga sebagai institusi yang memfasilitasi kebutuhan dasar insani (manusiawi), baik berupa fisik-biologis maupun sosiopsikologis; (b) sekolah, dijelaskan oleh Yusuf \& Sugandhi (2011:30) sekolah adalah lembaga pendidikan formal yang secara sistematis melaksanakan program bimbingan, pengajaran dan latihan dalam rangka membantu para siswa agar mampu mengembangkan potensinya secara maksimal; (c) lingkungan masyarakat, Nasution (2004:150) menjelaskan bahwa masyarakat terdiri atas sekelompok manusia yang menempati daerah tertentu, menunjukkan integrasi berdasarkan penglaman bersama. Lingkungan sekitar rumah akan memberikan pengaruh pertama kepada anak di luar lingkungan keluarga. Jika siswa berada dalam lingkungan orang-orang yang terpelajar yang baik-baik, mereka mendidik dan menyekolahkan anaknya, antusias terhadap masa depan anaknya, maka siswa akan terpengaruh untuk melanjutkan studi ke perguruan tinggi; (d) teman-teman, kelompok teman sebaya sebagai lingkungan sosial bagi anak berpengaruh cukup penting terhadap perkembangan siswa. Slameto (2010) mengungkapkan pengaruh-pengaruh dari teman bergaul siswa lebih cepat masuk dalam jiwanya dari pada yang kita duga. Teman yang baik akan berpengaruh positif terhadap diri siswa, begitu juga sebaliknya teman yang tidak baik akan berpengaruh buruk terhadap diri siswa. Jika teman sebayanya lebih banyak yang memutuskan untuk melanjutkan pendidikan setelah lulus sekolah, siswa juga akan memiliki keinginan yang sama karena pengaruh dari teman-temannya.

Berdasarkan uraian di atas, maka tujuan dari penelitian ini adalah untuk mengetahui faktor-faktor apa yang 
mempengaruhi minat siswa Madrasah Aliyah Negeri (MAN) Jembrana Kelas XII untuk melanjutkan studi ke perguruan tinggi Tahun Ajaran 2017/2018.

\section{METODE}

Penelitian ini dilakukan di Madrasah Aliyah Negeri (MAN) 2 Jembrana yang berlokasi di Jalaan Denpasar-Gilimanuk, Desa Yeh sumbul, Kecamatan Mendoyo, Kabupaten Jembrana-Bali. "Populasi adalah keseluruhan objek yang menjadi sasaran penelitian, baik itu seluruh anggota, sekelompok orang, kejadian atau objek yang telah dirumuskan secara jelas dan memiliki ciri-ciri atau karakteristik yang sama" (Sanusi, 2003: 65). Pada penelitian ini peneliti menggunakan sampel jenuh, dimana seluruh anggota populasi yang berjumlah 89 orang dijadikan sebagai sampel.

Uji instrumen yang dilakukan pada penelitian ini menggunakan. Uji validitas adalah untuk mengetahui tingkat kevalidan dari instrumen (kuesioner) yang digunakan dalam pengumpulan data. Uji validitas ini dilakukan pada siswa kelas XII SMA Muhammadiyah tahun ajaran 2017/2018 dengan jumlah responden sebanyak 30 orang, untuk mengetahui item-item yang tersaji dalam kuesioner benar-benar mampu mengungkapkan dengan pasti apa yang akan diteliti. Sugiyono (2004:126) mengungkapkan bahwa suatu instrumen dikatakan valid apabila koefisien korelasi antar butir lebih besar dari 0,30 dengan tingkat kesalahan alpha 0,05 . Pengujian validitas ini menggunakan bantuan aplikasi Statistical Package for Social Science (SPSS) 16.0 for windows dengan menggunakan uji statistik Corrected ItemTotal Correlation. Hasil uji validitas setiap instrumen dalam penelitian ini didapatkan dari hasil perbandingan antara nilai Connected Item-Total Correlation dengan r-tabel pada df $=\mathrm{N}-2$ dan alpha 0.05 dengan syarat ketentuan nilai Connected Item-Total Correlation harus lebih besar dari nilai pada r-tabel. Uji Reliabilitas. Arikunto (2005: 178) menyatakan "Reliabilitas menunjuk pada suatu pengertian bahwa sesuatu instrumen cukup dapat dipercaya untuk digunakan sebagai alat pengumpul data karena instrumen tersebut sudah baik". Pada penelitian ini, pengukuran reliabilitas dapat dilakukan hanya sekali dan kemudian mengukur korelasi antar jawaban dari pertanyaan. Uji validitas dan reliabilitas dihitung dengan menggunakan program SPSS 16.0 for Windows.

Data dalam penelitian ini dikumpulkan dengan metode kuesioner dan dokumentasi. Kuisioner merupakan metode pengumpulan data yang dilakukan dengan memberikan daftar pernyataan kepada responden untuk dijawab, terutama yang berkaitan dengan faktor-faktor yang mempengaruhi minat siswa untuk melanjutkan studi ke perguruan tinggi. Data dokumentasi dalam penelitian ini berupa nama-nama dan jumlah siswa Madrasah Aliyah Negeri (MAN) 2 Jembrana, data dokumentasi diperoleh dari bagian Tata Usaha Madrasah Aliyah Negeri (MAN) 2 Jembrana.

Sumber data dalam penelitian ini adalah data primer dan data sekunder. Data primer adalah data yang diperoleh secara langsung dengan menyebarkan kuisioner kepada siswa Madrasah Aliyah Negeri (MAN) 2 Jembrana kelas XII tahun ajaran 2017/2018 terkait faktor-faktor yang mempengaruhi minat siswa untuk melanjutkan studi ke perguruan tinggi. Data sekunder, yaitu data yang diperoleh dari sumber-sumber yang dianggap perlu dan ada hubungannya dengan penelitian seperti nama siswa dan jumlah siswa yang diperoleh dari bagian Tata Usaha Madrasah Aliyah Negeri (MAN) 2 Jembrana. Jenis data yang digunakan adalah data kualitatif berupa skor jawaban dari responden.

Sesuai dengan perumusan masalah, tujuan penelitian, dan jenis data yang dikumpulkan, maka analisis data yang digunakan dalam penelitian ini adalah analisis faktor. Menurut Suliyanto (2005:122) analisis faktor terdiri beberapa tahap, yaitu membuat matrik; menentukan jumlah faktor; rotasi faktor; interprtasi faktor, dan menentukan ketetapan model. Matrik korelasi dapat diidentifikasikan variabel-variabel tertentu yang tidak mempunyai korelasi dengan variabel yang lain, sehingga dapat dikeluarkan dari analisis. Untuk menguji ketepatan model 
analisis faktor, maka dapat digunakan Barlett's test of Sphericity yang dipakai untuk menguji bahwa variabel-variabel dalam sampel berkorelasi ataupun tidak berkorelasi. Hasil Barlett's test of Sphericity menunjukkan apakah hubungan antara variabel-variabel signifikan atau tidak. Statistik lain yang berguna adalah pengukuran kelayakan sampel Kaiser Meyer Olkin (KMO). Analisis faktor dianggap layak untuk dianalisis lebih lanjut jika besaran KMO nilainya minimal 0,50 . Besaran ini digunakan untuk mengukur derajat korelasi antar variabel dengan kriteria Measure of Sampling Adequacy $(\mathrm{MSA}) \geq 0,5$.

Menentukan jumlah faktor. Variabel disusun kembali berdasarkan pada korelasi hasil langkah pada butir dua untuk menentukan faktor yang diperlukan mewakili data. Untuk menentukan berapa faktor yang diterima secara empirik dapat dilakukan berdasarkan besarnya eigenvalue setiap faktor yang muncul. Semakin besar eigenvalue setiap faktor, semakin representatif faktor tersebut untuk mewakili sekelompok variabel. Faktorfaktor ini yang dipilih adalah faktor yang mempunyai eigenvalue sama dengan atau lebih dari 1. Jika eigenvalue kurang dari 1, maka faktor tersebut tidak bisa diterima untuk mewakili data yang diteliti. Rotasi faktor. Apabila hasil penyederhanaan faktor dalam matrik faktor memperlihatkan hubungan antara faktor dengan variabel individu, tetapi dalam faktor-faktor tersebut terdapat banyak variabel yang berkorelasi sehingga sulit diinterpretasikan. Dengan menggunakan rotasi faktor matrik, matrik faktor ditranspormasikan ke dalam matrik yang lebih sederhana sehingga mudah untuk diinterpretasikan. Dalam perilaku ini digunakan rotasi varimax. Interpretasi faktor, Interpretasi faktor dilakukan dengan mengelompokkan variabel yang mempunyai faktor loading tinggi ke dalam faktor tersebut. Untuk menginterpretasikan hasil penelitian ini, faktor loading minimal 0,5 . Variabel yang mempunyai faktor loading kurang dari 0,5 dikeluarkan dari model. Menentukan ketepatan model. Tahap terakhir dari analisis faktor adalah mengetahui apakah model mampu menjelaskan dengan baik. Fenomena yang ada perlu diuji dengan teknik Principal Component Analisis (PCA) yaitu dengan melihat jumlah resudial antara korelasi yang diamati dengan korelasi yang direproduksi. Dalam penelitian ini, untuk mempermudah proses perhitungan dan untuk mendapatkan hasil perhitungan yang akurat dalam analisis data, peneliti menggunakan bantuan alat hitung berupa program SPSS 21.0 for Windows. Data yang didapat dari kuisioner masih berupa data ordinal, sedangkan analisis data yang dipakai untuk membuktikan kebenaran pengujian analisis faktor mengisyaratkan minimal data interval, maka data ordinal tersebut perlu ditingkatkan menjadil data interval, sehingga data ordinal tersebut perlu ditingkatkan skala pengukurannya menjadi skala interval melalui "Method of Succestive Interval".

\section{HASIL DAN PEMBAHASAN Hasil}

Berdasarkan hasil analisis data menunjukkan bahwa faktor-faktor yang mempengaruhi minat siswa Madrasah Aliyah Negeri (MAN) 2 Jembrana kelas XII untuk melanjutkan studi ke perguruan tinggi dapat dijelaskan oleh masing-masing faktor. Nilai Total Variance Explained digunakan untuk mengetahui presentase dari ke 9 (sembilan) variabel yang dianalisis, yaitu faktor bakat, kepribadian, motivasi, prestasi, sikap, keluarga, sekolah, lingkungan masyarakat, dan teman-teman. Hasil Analisis faktor menggunakn bantuan program SPSS 21.0 for Windows pada taraf signifikansi 5\%, berdasarkan hasil penelitian, faktor bakat memiliki eigenvalues sebesar 3,795 dengan nilai varian sebesar $42,163 \%$; faktor kepribadian memiliki eigenvalues sebesar 1,789 dengan nilai varian sebesar 19,877\%; faktor motivasi memiliki eigenvalues sebesar 0,870 dengan nilai varian sebesar 9,670\%; faktor prestasi memiliki eigenvalues sebesar 0,589 dengan nilai varian sebesar $6,546 \%$; faktor sikap memiliki eigenvalues sebesar 0,542 dengan nilai varian sebesar $6,027 \%$; faktor keluarga memiliki eigenvalues sebesar 0,467 dengan nilai varian sebesar $5,186 \%$; faktor sekolah memiliki eigenvalues sebesar 0,420 dengan nilai 
varian sebesar 4,663\%; faktor lingkungan masyarakat memiliki eigenvalues sebesar 0,306 dengan nilai varian sebesar 3,396\%; faktor teman-teman memiliki eigenvalues sebesar 0,223 dengan nilai varian sebesar $2,473 \%$.

Untuk menentukan banyaknya faktor yang mempengaruhi atau yang mampu menjelaskan faktor yang mempengaruhi minat siswa melanjutkan studi ke perguruan tinggi pada siswa kelas XII, maka dilakukan ekstraksi faktor. Ekstraksi faktor dapat dijelaskan oleh total presentasi varians dari masing-masing faktor utama. Nilai Total Variance Explained digunakan untuk mengetahui banyaknya faktor yang terbentuk. Susunan eginevalue diurutkan dari yang terbesar sampai yang terkecil. Berdasarkan tabel hasil analisis data yang dilakukan, maka faktor yang memiliki eignevalue $>1$ adalah faktor bakat dengan nilai eignevalue sebesar $42,163 \%$ dan faktor kepribadian dengan nilai eignevalue sebesar $19,877 \%$. Berarti total nilai varianced explained dari ke 2 (dua) faktor tersebut mampu menjelaskan sebesar $62,040 \%$.

Setelah semua faktor memiliki nilai yang mencukupi, tahap selanjutnya adalah melakukan proses inti dari analisis faktor, yaitu melakukan ekstraksi terhadap sekumpulan variabel yang sudah ada sehingga terbentuk satu atau beberapa faktor. Rotasi faktor dilakukan untuk mempermudah intrepretasi dalam menentukan variabel-variabel mana saja yang tercantum dalam suatu faktor. Dalam penelitian ini digunakan varimax rotation. Interpretasi faktor dilakukan dengan mengelompokkan variabel yang mempunyai factor loading tertinggi di dalam faktor tersebut. untuk menginterpretasikan variabel dalam penelitian ini, minimal faktor loadingnya bernilai 0,5. Berdasarkan hasil analisis data yang dilakukan bahwa faktor yang mempengaruhi minat siswa melanjutkan studi ke perguruan tinggi dapat dikelompokkan menjadi 2 faktor. Faktor 1 (satu) terbentuk dari faktor bakat (X1) dengan loading factor sebesar 0,626; faktor kepribadian (X2) dengan loading factor sebesar 0,771 ; faktor motivasi (X3) dengan loading factor sebesar 0,854 ; faktor prestasi (X4) dengan loading factor sebesar 0,883; faktor sikap (X5) dengan loading factor sebesar 0,541 ; faktor sekolah (X7) dengan loading factor sebesar 0,734. Faktor ke 2 (dua) terbentuk dari faktor keluarga (X6) dengan loading factor sebesar 0,811; faktor lingkungan masyarakat (X8) dengan loading factor sebesar 0,799; faktor teman-teman (X9) dengan loading factor sebesar 0,765.

Penentuan faktor yang paling dominan mempengaruhi minat siswa kelas XII Madrasah aliyah Negeri (MAN) 2 Jembrana untuk melanjutkan studi ke perguruan tinggi menggunakan parameter koefisien varimax. Secara rinci hasil ringkasan rotasi dari matriks faktor memuat nilai varimax rotation dapat dijelaskan faktor-faktor yang dominan mempengaruhi minat siswa Madrasah Aliyah Negeri (MAN) 2 Jembrana kelas XII untuk melanjutkan studi ke perguruan tinggi adalah faktor bakat dengan nilai varimax rotation $42,163 \%$. Artinya kejelasan dari dimensi minat siswa Madrasah Aliyah Negeri (MAN) 2 Jembrana kelas XII untuk melanjutkan studi ke perguruan tinggi adalah bakat yang paling mendominasi sebesar 42,163\%, dan faktor kepribadian dengan nilai varimax rotation $19,877 \%$.

\section{Pembahasan}

Berdasarkan hasil analisis faktor, maka dalam penelitian ini ditemukan 9 (sembilan) faktor yang mempengaruhi minat siswa Madrasah Aliyah Negeri (MAN) 2 Jembrana kelas XII untuk melanjutkan studi ke perguruan tinggi yaitu bakat, kepribadia, motivasi, prestasi, sikap, keluarga, sekolah, lingkungan masyarakat, dan teman-teman. Hal ini sesuai dengan teori yang dikemukakan oleh Slameto (2010) bahwa minat melanjutkan studi dipengaruhi oleh faktor bakat, keluarga, lingkungan masyarakat, dan teman-teman. Pendapat ini hampir sama dengan teori Purwanto (2003) yaitu sikap, minat, sifatsifat pribadi, bakat, motivasi, keluarga, guru, masyarakat dan teman-teman.

Faktor bakat dan kepribadian merupakan faktor yang psling dominan mempengaruhi minat siswa Madrasah Aliyah Negeri (MAN) 2 Jembrana kelas XII untuk melanjutkan studi ke perguruan 
tinggi. Faktor bakat paling dominan dibandingkan faktor kepribadian karena faktor bakat merupakan kemampuan yang berasal dari dalam diri siswa itu sendiri. Hal ini sesuai dengan pendapat Slameto (2010:57) bakat adalah kemampuan untuk belajar. Bakat akan mempengaruhi tinggi rendahnya prestasi belajar bidang-bidang studi tertentu. Bakat mempengaruhi dalam pemilihan bidang saat melanjutkan studi ke perguruan tinggi.

Kepribadian merupakan faktor penting dalam minat siswa Madrasah Aliyah Negeri (MAN) 2 Jembrana kelas XII untuk melanjutkan studi ke perguruan tinggi karena kepribadian merupakan cara seorang individu bereaksi dan berinteraksi terhadap sesuatu atau individu lain. Hal ini sesuai dengan pendapat Agus Sujanto (2004) kepribadian adalah suatu totalitas psikofisis yang kompleks dari individu, sehingga nampak dalam tingkah lakunya yang unik.

\section{SIMPULAN DAN SARAN Simpulan}

Simpulan dari penelitian ini adalah sebagai berikut (1) faktor-faktor yang mempengaruhi minat siswa Madrasah Aliyah Negeri (MAN) 2 Jembrana kelas XII untuk melanjutkan studi ke perguruan tinggi, yaitu bakat $\left(X_{1}\right)$, kepribadian $\left(X_{2}\right)$, motivasi $\left(X_{3}\right)$, prestasi $\left(X_{4}\right)$, sikap $\left(X_{5}\right)$, keluarga $\left(X_{6}\right)$, sekolah $\left(X_{7}\right)$, lingkungan masyarakat $\left(X_{8}\right)$, dan teman-teman $\left(X_{9}\right)$; (2) faktor paling dominan yang mempengaruhi minat siswa melanjutkan studi ke perguruan tinggi pada siswa kelas XII Madrasah Aliyah Negeri (MAN) 2 Jembrana adalah faktor bakat dengan nilai varimax rotation sebesar $42,163 \%$, dan faktor kepribadian dengan nilai nilai varimax rotation sebesar $19,877 \%$.

\section{Saran}

Berdasarkan hasil, pembahasan dan simpulan maka diajukan saran sebagai berikut. (1) Bagi siswa agar lebih mengembangkan bakat yang telah dimiliki karena bakat mempengaruhi prestasi belajar yang nantinya akan mempengaruhi minat untuk melanjutkan studi ke perguruan tinggi; (2) bagi orang tua agar selalu memberi dorongan motivasi kepada anak agar anak lebih bersemangat dan giat untuk belajar.

\section{DAFTAR PUSTAKA}

Anwar, Sanusi. 2003. Metodologi Penelitian Praktis Untuk IImu sosial dan Ekonomi. Malang: Buntara Media.

Arikunto, Suharsimi. 2005. Manajemen Penelitian. Jakarta: Rineka Cipta.

Djaali. 2008. Psikologi Pendidikan. Jakarta: Bumi Aksara.

------- 2012. Psikologi Pendidikan. Jakarta: Rineka Cipta.

Djamarah, S. B. 2011.Psikologi Belajar. Jakarta: Rineka Cipta.

Hasbullah. 2008. Dasar-dasar IImu Pendidikan. Jakarta: PT. Raja Grafindo Persada.

Idi, Abdullah 2011. Sosiologi Pendidikan. Jakarta: Rajagrafindo Persada.

Nasution. 2004. Sosiologi Pendidikan. Jakarta: Bumi Aksara.

Notoatmodjo, Soekidjo. 2003. Pendidikan dan Perilaku Kesehatan. Jakarta: PT Rineka Cipta.

Purwanto, Ngalim. 2003. Psikologi Pendidikan. Bandung: PT. Remaaja Rosda Karya.

Rochman, Abror. 1984. Psikologi Pendidikan. Yogyakarta: Nur Cahaya.

Rohman, Arif. 2009. Memahami Pendidikan IImu Pendidikan. Yogyakarta: LaksBang Mediatama.

Sardiman. 2011. Interaksi dan Motivasi Belajar Mengajar. Jakarta: Rajagrafindo Persada.

Siswoyo, Dwi. 2007. Ilmu Pendidikan. Yogyakarta: UNY Pers.

Slameto. 2010. Belajar dan Faktor-faktor yang Mempengaruhinya. Jakarta: Rineka Cipta.

Sobur, Alex. 2011. Psikologi Umum. Bandung: Pustaka Setia. 
Sugiyono. 2004. Metode Penelitian Bisnis.

Bandung: CV Alfabeta.

Suliyanto. 2011, Ekonomika Terapan:

Teori dan Aplikasi dengan SPSS.

Yogyakarta: Andi.

Syah, Muhibbin. 2004. Psikologi Pendidikan dengan pendekatan baru. Bandung: Rosdakarya.

Undang-Undang Republik Indonesia Nomor 20 Tahun 2003 tentang Sistem Pendidikan Nasional. 2006. Jakarta: diperbanyak oleh Fokusmedia.

Yusuf, Syamsu \& Nurhisan A. J. 2008. Landasan dan Bimbingan Konseling. Bandung: Remaja Rosdakary

Yusuf, Syamsu \& Sugandhi, M. N. 2011. Perkembangan Perserta Didik.

Bandung: PT. Rajagrafindo Persada. 
